\title{
Persatuan Pembangunan Party in Nanggroe Aceh Darussalam Province 1973-1998
}

\author{
Alfian$^{1}$, Suprayitno', Warjio ${ }^{1}$ \\ ${ }^{1}$ Universitas Sumatera Utara (USU), Medan \\ ratna4@usu.ac.id
}

\begin{abstract}
After the establishment of PPP in the provincial area which is explained in the previous section, it was immediately based on instructions from the center to establish DPCDPC in Daerah Istimewa Aceh Province. The establishment of the Branch Board (DPC) began in 1974. This article uses a theoretical and approach approach in pilitik science. For research methods, this study uses historical methods. This article explains how PPP can exist or survive in the face of government party hegemony namely Golkar. In this research, the campaign system, election results, PPP vision and party goals are also described.
\end{abstract}

Keyword : PPP (Persatuan Pembangunan Party); Aceh; Election

\section{Introduction}

During the New Order government, it was known as the era of national development which sought to improve the condition of the Indonesian people. By putting forward the development mission, the New Order government made improvements to the system of implementing the government which during the Old Order government did not work with it. As a development order, the New Order had three characteristics in implementing a development strategy policy consisting of development, agriculture and industrialization, and Indonesian political integration. ${ }^{1}$ From the policy of the development strategy, one of them is development in the political field where the government makes policies by combining various socio-political forces into three groups.

Based on this, the government made a policy by simplifying the party or social political organization in Indonesia (orsospol). Simplification of political organizations is considered as a way out to achieve the political stability that the New Order government wants to achieve. ${ }^{2}$ On this policy, the government then merged the political organizations into three major groups namely the Golongan Karya (Golkar), Partai Demokrasi Indonesia (PDI), and Partai Persatuan Pembangunan (PPP). Partai Persatuan Pembangunan is a combination of Islamic parties consisting of Parmusi, PSII, NU and Perti. ${ }^{3}$ The incorporation of Islamic parties was a joint declaration of Islamic parties on January 5, 1973 in Jakarta. The merging of the four parties is an implication of the policies of the New Order government to simplify political parties, namely through the Decree of the MPRS No. XXII / MPRS / 1966 which one of the objectives is to achieve development characterized by "Spirituil-Material". ${ }^{4}$

The establishment of the United Development Party in Indonesia after the fusion of Islamic parties, party management was immediately formed in each of the provinces in Indonesia. The formation of regional management is an attempt to face the next election year.

Based on this policy, PPP management was formed in each province, including in Daerah

\footnotetext{
${ }^{1}$ M. Dawan Rahardjo, Intelektual Intelegensia dan Perilaku Politik Bangsa: Risalah Cendikiawan Muslim, Bandung: Mizan, 1993, pp. 321-322.

2 H. M. Dja'far Siddiq, PPP Menggagas Reformasi Membangun Indonesia Baru, Jakarta: Tanpa Penerbit, 2003 , p. 7.

${ }^{3}$ Syamsuddin Haris, PPP dan Politik Orde Baru, Jakarta: PT. Gramedia Widiasarana Indonesia, 1991, pp. 8-9.

${ }^{4}$ T. Hasyim Thayeb, Sejarah Singkat Fusi 4 Partai Islam, Tanpa Tempat: Tanpa Penerbit, Tanpa Tahun Terbit, p.1.
} 
Istimewa Aceh Province. The aim of establishing PPP party in each region is to unite Muslims sheltered by political organizations. After fusion, during the New Order period PPP was the only Islamic party in Indonesia. ${ }^{5}$

\section{Method}

This research uses historical methods. In the historical methods, there are several steps which include heuristics (source collection), verification (source criticism), interpretation and historiography (writing). ${ }^{6}$ All of these stages are very important because from these four stages the researcher can be directed towards completing this thesis research. The first stage is collecting resources, the sources collected are many historical sources stored in the National Archives of the Republic of Indonesia (ANRI) and The National Library of the Republic of Indonesia (PNRI), both of which are in Jakarta. In general, the sources sought and collected which were then used as information material for this study consisted of two major groups. First, the primary written sources are the archives found at ANRI. Second, are secondary written sources, namely books, newspapers, periodicals, atricles, and so on, both in Indonesian and English.

\section{Discussion}

\subsection{Background to the Establishment of PPP in Aceh}

Long before political parties were present in Aceh, there were already political organizations and in the name of religion. The organization in question is PUSA (Persatuan Ulama Seluruh Aceh). This organization was born from the decision of the ulama deliberations throughout Aceh which was held on 5 - 8 May 1939, in Peusangan, Matang Glumpang. ${ }^{7}$

The two initiators or initiative takers were: Teungku Abdurrachman Meunasah Meucap and Teungku Muhammad Daud Beureueh with the blessing and protection of Teuku Chiek Muhammad Johan Alamsyah, Uleebalang Peusangan. During the reign of the Old Order, especially during the government with a guided democratic system, the Masyumi Party which was in fact an Islamic party was suspected by the government and limited in scope because it was allegedly going to change the state ideology from Pancasila to Islamic law.

In Aceh, where the people are known as devout Muslims, there are also some people who are members of the Masyumi party besides those who are followers of David Beureuh's Darul Islam movement. In various regions, Masyumi branches such as Cianjur and Aceh Branches helped the Darul Islam movement in their region, although the form of support was not very clear. ${ }^{8}$

Since 1960, political developments in Aceh have shown changes. The dissolution of the Masyumi party in 1960 resulted in its leaders who were not members of DI / TII starting to foster the movement of other Islamic organizations such as Muhammadiyah. Instead the DI /

\footnotetext{
${ }^{5}$ Syamsuddin Haris, PPP dan Politik Orde Baru, Jakarta: PT. Gramedia Widiasarana Indonesia, 1991, pp. 8-9.

${ }^{6}$ Kuntowijoyo, Pengantar Ilmu Sejarah, Yogyakarta: Bentang Budaya, 2001, p. 91.

${ }^{7}$ Rusdi Sufi, Peranan Tokoh Agama dalam Perjuangan Kemerdekaan 1945-1950, Jakarta: Departemen Pendidikan dan Kebudayaan, 1997, p. 23.

${ }^{8}$ Remy Madinier, Partai Masyumi: Antara Godaan Demokrasi dan Islam Integral, Bandung: Penerbit Mizan, 2013, pp. 168-169.
} 
TII leaders began to be active in PSII. But there are also some Masyumi members who joined PSII. This indicates that the political movement of the Acehnese people at that time had progressed.

Judging from political developments, the political turmoil of the Acehnese people began to appear after the establishment of Muhammadiyah in Aceh in the 1950s. This is based on the strong influence of the ulamas who evoke the dayah-based education system (pesantren). Then, there were also groups which moved the tarekat, especially the Satariyah order. In addition there are young people who are influenced by modern education, most of whom are followers of PUSA playing a more reformist politics. This movement was then affiliated with Muhammadiyah. Then to attack the influence of Partai Komunis Indonesia (PKI) in Aceh, Parmusi (Partai Muslimin Indonesia) was formed in 1968 which was soon formed PII (Indonesian Islamic Students). PII then held training aimed at regeneration which crushed the influence of communism. Besides that, it is also trained to regenerate political leadership and exercise discipline in organizational life. ${ }^{9}$

Aceh people who already have Islamic organizations through education in dayah (Islamic boarding schools), can still live the life of their organizations as long as they comply with the regulations set by the central government. Ulama, who were previously members of the Masyumi, after being banned by the government, these scholars joined other Islamic political organizations such as PSII (Partai Syarikat Islam Indonesia), Parmusi (Partai Muslimin Indonesia) and Perti (Persatuan Tarbiyah Islamiyah). ${ }^{10}$ The birth of Parmusi in 1968 was a very effective channel for the Muhammadiyah youth movement. Parmusi supporting elements are some civil and military government employees, teachers, both public school teachers and religious schools, traders and farmers who are members of Muhammadiyah and Al-Wasliyah, and students who are moved in the PII. Although the PII Aceh region stated that it would win the Islamic group in the 1971 General Election, the PII organization tended to a party namely Parmusi. This tendency was evident with the role of Abdul Malik Raden as PII leader who later became a member of Parmusi.

Besides Parmusi, several other Islamic parties are PSII, Perti Islamic Party and NU (Nahdatul Ulama). Of the three Islamic parties, the Perti Islamic Party has a large mass and its position is the second majority in the general election. The sympathizers of the Islamic Party of the Islamic Party are groups consisting of a minority of employees, a minority of small traders, the majority of farmers and followers of the tarekat in the dayah-dayah found in Aceh. The role of the Perti is seen from the existence of the dayah even though it is still a traditional form. Fostering its members through the development of dayah-dayah in gampong (village). ${ }^{11}$

The life of PSII as an Islamic organization does not reveal a real social role. When examined by their leaders, they come from the former Darul Islam and the Masyumi political elite. It can be interpreted that this shift in the political elite is a counterweight to other political forces. Political crystallization in the PSII was a political balance for Parmusi after 1968. The characteristics of the PSII were the lack of participation of a small role in the social field. So this makes PSII less famous. The other small party is NU, the NU party is a party whose social activities are limited to conducting recitations so that they are not well known to the public at

\footnotetext{
9 Alfian, loc. cit.

${ }^{10}$ Interview with Nur Dahri Ibrahim Naim, tanggal 14 July 2018 in Banda Aceh.

${ }^{11}$ Alfian, op. cit., p. 73.
} 
large. ${ }^{12}$ From this statement, the Islamic parties were the parties participating in the 1971 General Election. The results of the 1971 General Election can be detailed as follows: Golkar got 482,297 votes, Parmusi got 182,937 votes, Perti got 127,982 votes, the Party NU got 88,995 votes. Sound and PSII get a sound of 74,573 sounds. From these results it can be seen that Golkar became the winning party by obtaining a vote of $50.41 \%$, the two Parmusi with a vote of $19.12 \%$, third is Perti by obtaining ballots of $13.37 \%$, the fourth is NU Party by obtaining votes of $9.3 \%$ and the last is PSII with a vote of $7.8 \% .^{13}$

The political fusion that occurred during the New Order government was carried out on the basis of TAP MPRS no. XXII / MPRS / 1966 whose contents are to mandate the simplification of social and political organizations in Indonesia. ${ }^{14}$ This simplification of social and political organizations is considered a way out to achieve the political stability that the New Order government wants to achieve. Although the real purpose of the simplification is to avoid political parties oriented towards ideological politics. ${ }^{15}$ For political parties in Indonesia, this certainly brings their own temptation, especially regarding the fate of the party and their political struggle going forward. The absence of a clear enough picture of the goodness of the political fusion they will do, because each party feels that political fusion is not yet sufficient enough to gather political aspirations in each party. ${ }^{16}$

From the decision of TAP MPRS no XXII / MPRS / 1966, there has been an order to dissolve the party into three groups. However, the smelting process takes a long time because there are various rejection and long processes. The fusion process is intended to realize improvements in Indonesian politics. The New Order government considered the presence of many parties or multiparties to be ineffective but increasingly aggravated the political atmosphere, as happened during the Old Order government. But Moh. Hatta said that the number of parties was a form of developing politics in Indonesia and as a barometer of democracy in a country. The New Order government was seen as the cause of Indonesian political instability because of the possibility of intense inter-party competition. Some considered the formation of this group to be a way of launching fusion efforts that had been emphasized by the government, and if such conditions were realized then these Islamic parties were considered has lost in the New Order's political strategy. Some parties did refuse, especially from the PSII party. The PSII DPP forbade any element of its party at the branch or regional level to participate in the discussion concerning fusion issues. ${ }^{17}$

Efforts to legalize this matter, PSII led by M. Ch. Ibrahim and Bustaman issued instruction No. 193 dated 18 October 1972. This situation naturally hampered the performance of the PSII party leaders at the DPW and DPC's notice for fusion talks. ${ }^{18}$ After the emergence of the rival PSII at the central level under the leadership of H. Anwar Tjokroaminoto, every DPW and the PSII DPC throughout Indonesia could continue the conversation against fusion. After the rival PSII, the fusion process in each region, both the DPW and the DPC, will return

${ }^{12}$ Ibid., p. 74.

${ }^{13}$ Duta Pancasila, 30 July 1971.

${ }^{14}$ H. M. Dja'farSiddiq, PPP Menggagas Reformasi Membangun Indonesia Baru, Jakarta: TanpaPenerbit, 2003, p. 7.

${ }^{15}$ P. K. Poerwantana, Partai Poltik di Indonesia, Jakarta: Rineka Cipta, 1994, p. 81.

${ }^{16}$ Abdul Rahman Lubis, "Partai Persatuan Pembangunan (PPP) di Medan tahun 1973-1977”, Skripsi S1 belum diterbitkan, Medan: Faculty of Literature History Department USU, 2007, P. 20.

${ }^{17}$ Abdul Azis Thaba, Islam dan Negara dalam Politik Orde Baru, Jakarta: Gema Insani Press, 1966, P. 237.

${ }^{18}$ Ibid., p. 238. Also see Dja'far Siddiq, op. cit., p. 8. 
to the discussion regarding fusion. The fusion process of Islamic parties in the regions seems to be moving slowly because indeed every DPW and DPC follow the instructions issued by the Central Board of each party.

After the 1971 elections, the New Order government through the laws of political parties simplified the political system in Indonesia by establishing two political parties and one class of works. Four Islamic political parties participating in the elections in 1971 such as Parmusi, NU, PSII and Perti on January 5, 1973 declared a merger under the name of the United Development Party signed by five declarators who were leaders of the four Islamic parties participating in the 1971 Election and a faction chair the United Development group, or a combination of factions from four Islamic parties in the DPR-RI. The policy then applies in all regions of Indonesia, including in Aceh Province. In Aceh, the fusion policy of political parties follows what has been determined by the central government and the policies of the parties that are fusing themselves. The parties at the center instruct themselves to immediately do the same in the regions. This policy was then welcomed openly by the four Islamic parties based in Aceh to fuse by changing the name of Persatuan Pembangunan Party. ${ }^{19}$

\subsection{PPP Achievements in Aceh}

In the 1977 elections the first election was attended by PPP. Of course this is the most historic experience or moment for PPP. The elections in 1971 were felt different from the previous elections, because the number of participants in the 1971 General Election was 10 parties, whereas in 1977 there were only three parties consisting of PPP, PDI, and Golkar. The implementation of this election was intended to elect members of the MPR, the DPR which included the central parliament, the DPRD level I and the DPRD level II. The rules for the election of MPR and DPR members have been stipulated in Law No. 15 of 1969 concerning General Elections of Members of the People's Consultative Body. ${ }^{20}$

The results of the 1977 elections, as a relatively new party, gave a surprise by appearing as a winning party in Aceh and Jakarta. In Aceh PPP, 647,414 votes outperformed Golkar's 461,884 votes. Whereas in Aceh, the PDI only received 17,065 votes. The defeat suffered by Golkar in Aceh was considered because the Aceh people still held firm to their Islam, so the PPP succeeded in gaining a dominant voice in this area. ${ }^{21}$ From the results of the vote above, the number of seats for board members who are entitled to serve as members of the Level I DPRD is PPP got 18 seats, Golkar got 13 seats, PDI got 1 seat. ${ }^{22}$

In the next election held in 1982, the determination of the results of the general election stipulated that PPP was again the winning party. PPP won with 771,995 votes, while Golkar received 483,763 votes and PDI got 54,435 votes. From the results of the vote, the number of seats for board members who were entitled to serve as members of the Level I DPRD is that PPP got 19 seats, Golkar got 12 seats, PDI got 1 seat. ${ }^{23}$ The implementation of the 1987 General Election was an implementation of Pancasila democracy as the basis and ideology of the State and the philosophy of the life of the Indonesian nation, so the implementation of the election results was the culmination of a democratic party whose implementation was arranged or

\footnotetext{
${ }^{19}$ Interview with Nur Dahri Ibrahim Naim, 14 July 2018 in Banda Aceh.

${ }^{20}$ Anonymous, 60 Tahun Berita Waspada, Medan: Waspada, 2006, p. 84.

${ }^{21}$ Ibid.,p. 86.

22 Inventory Archives of KPU 1971-1999 No. 003.1

${ }^{23}$ Inventory Archives of KPU 1971-1999 No. 003.1
} 
arranged in accordance with the functions of each activity. The implementation of the determination meeting results of the general election for the membership of the Aceh DPRD I held by the Aceh regional level I election committee was open to the public and followed and witnessed by the parties and organizations participating in the election, government officials and community leaders. Based on the election results determination meeting in Aceh, Persatuan Pembangunan Party obtained a vote of 659,505 votes, Golkar 804. 121 Voting, Demokrasi Indonesia Party obtained 78, 219 votes. With this vote, each political party and organization won the seat of the 1st Regional Parliament as follows: Persatuan Pembangunan Party obtained 15 representatives, Golkar obtainde 18 representatives, the Indonesian Democratic Party obtained 1 representative. ${ }^{24}$

The implementation of the 1992 Elections in Aceh proceeded safely and smoothly. The implementation of the 1992 General Election was carried out by the regional election committee of Aceh Province. The 1992 General Election was held openly witnessed by election participant parties and legislative candidates both level II and level I. The results of the 1992 elections in Aceh Province Persatuan Pembangunan Party won a vote of 605,424 votes, Golkar won 1,073,428 votes and Demokrasi Indonesia Party gained 129,538 votes. From these votes, each party and social organization obtained Persatuan Pembangunan Party to get 15 seats, Golkar won 27 seats, and Demokrasi Indonesia Party obtained 4 seats. $^{25}$

In accordance with presidential decree No. 86 of 1996 that the Pemelelegegion for the 1997 General Election was held on Thursday, May 29, 1997, simultaneously in all polling stations in all regions of Indonesia including Daerah Istimewa Aceh Province. Here there are 7,352 polling stations (TPS) scattered throughout the territory of the Level II Region. The vote count is conducted at the polling station, based on the results of the vote count meeting conducted by the Panitai of the Aceh Regional Election I on 17 June 1997 witnessed by witnesses and leaders of the Organization Participants in the Election bot PPP, Golkar and PDI were attended by Panwaslak I and a number of related institutions. Determination of the 1997 election results was carried out at once after the meeting. With this vote, each political party and organization won the seat of the 1st Regional Parliament as follows: Persatuan Pembangunan Party obtained 12 representatives, Golkar received 23 representatives, Demokrasi Indonesia Party obtained 1 representative. ${ }^{26}$

\section{Conclusion}

The PPP program was established by the PPP DPP in Jakarta on February 13, 1973. The basic party program was organized with the aim of providing guidance on the things PPP would do as a political party. It is this basic program which will influence the PPP's political struggle during the New Order Government. The formulation of the basic party program is based on an agreement that has been taken from all elements in the PPP. So that this basic program can be accepted and understood by every element of PPP starting from level I to the level of DPW and DPC.

\footnotetext{
${ }^{24}$ Inventory Archives of KPU 1971-1999 No. 004.1

${ }^{25}$ Inventory Archives of PPP Aceh year 1992.

${ }^{26}$ Inventory Archives of KPU 1971-1999 No. 006.1
} 
PPP realized how important it was to have a principle in partying. This principle is used as a handle of life, as well as the party's life beliefs that must be maintained Istiqamah (consistent). The PPP realizes that the struggle without principle is a moral deviation that must be avoided. Because by principle, PPPs can hold fast to the basic matters concerning identity, party principles, party programs and the vision and mission of the party that is able to apply it to clear attitudes and actions. Apart from that, as an Islamic party, PPP always propagates its political principles which are based on Islamic law. This propaganda concerns the principles that are lived in the party system.

The Islamic aspect became the main standard in responding to the policies discussed by considering the suitability between the draft law and the teachings of Islam. This is an important part because PPP is an Islamic based party while also having the responsibility to maintain the continuity of ukhuwah islamāmi (religious brotherhood) ukhuwah bashariyah (humanitarian considerations), and ukhuwah wațaniyah (national considerations). All policy making processes are based on these three considerations through a mechanism that allows various aspirations to be comprehensively articulated. This can happen if the democratic system through deliberation to reach consensus can be implemented effectively.

In this context, the PPP carries out steps to strive to realize it through ways and mechanisms in democracy, both in the form of laws and government regulations. Third, Islamic values believed by a group of Muslims, but not necessarily believed by other Muslim groups. For example, it concerns issues of ikhtilafiyah (disputes among ulama), such as the issue of headscarves, women's leadership, or shaking hands with not their mahrahm. In this matter, PPP placed it as specific issues and was directly related to the internal interests of Muslims who could not be intervened by the state, but resolved by the ulama.

\section{References}

Inventory Archives of KPU 1971-1999 No. 002. Inventory Archives of KPU 1971-1999 No. 003.1 Inventory Archives of KPU 1971-1999 No. 004.1 Inventory Archives of KPU 1971-1999 No. 004.2 Inventory Archives of KPU 1971-1999 No. 005.1 Inventory Archives of KPU 1971-1999 No. 006.1 Inventory Archives of KPU 1971-1999 No. 006.7

Arsip DPW PPP ACEH, “Anggaran Dasar/Anggaran Rumah Tangga dan Khittah Perjuangan Partai Persatuan Pembangunan” tahun 1973.

Arsip DPW PPP ACEH, "Struktur Organisasi Partai Persatuan Pembangunan tahun 1973" 13 January 1973, dokumentasi T. Hasyem Thayeb.

Arsip DPW PPP ACEH, "Struktur Organisasi Partai Persatuan Pembangunan tahun 1973" 14 June 1973, dokumentasi T. Hasyem Thayeb.

Anonim,1977,Anggaran Dasar dan Anggaran Rumah Tangga Partai Persatuan Pembangunan, Jakarta: Tanpa Penerbit.

Anonim, 2003, 30 Tahun Bersama Ummat, Jakarta: DPP PPP.

Anonim, 2011, Rumah Besar Umat Islam, Ketetapan Muktamar VII Partai Persatuan Pembangunan, Jakarta: DPP PPP.

Budiardjo, Miriam, 2009,Dasar-Dasar Ilmu Politik, Jakarta: PT. Gramedia Pustaka Utama. 
Effendy, Bahtiar, 1994, "Islam and the State: The Transformation of Islamic Political Ideas and Practices in Indonesia" Ph.D Dissertation belum diterbitkan, Ohio: The Ohio State University.

Hakim, Sudarnoto Abdul, 1993, "The Partai Persatuan Pembangunan: The Political Journey of Islam under Indonesia's New Order" M.A Thesis belum ditebitkan, Montreal: Institute of Islamic Studies Mgrill University.

Hamid, Ahmad Farhan, 2008, Partai Politik Lokal di Aceh Desentralisasi Politik dalam Negara Kebangsaan, Jakarta: Penerbit Kemitraan.

Haris, Syamsuddin, 1991,PPP dan Politik Orde Baru, Jakarta: PT. Gramedia Widiasarana Indonesia.

Ihsan, A. Bakir, "Kebijakan Berdimensi Syariah dalam Sistem Partai Politik Islam", dalam AHKAM: Jurnal Ilmu Syariah, Volume 17, Number 2, 2017.

Kartodirdjo, Sartono, 1992, Pendekatan Ilmu Sosial dalam Metodologi Sejarah, Jakarta: PT. Gramedia Pustaka Utama.

Kazim, Musa dan Alfian Hamzah, 1999, 5 Partai dalam Timbangan (PAN, PBB, PDI-P, PKB, PPP): Analisis dan Prospek, Bandung: Pustaka Hidayah.

Madinier, Remy, 2013, Partai Masyumi: Antara Godaan Demokrasi dan Islam Integral, Bandung: Mizan Publisher.

Magenda, Burhan, 1992, Sikap Politik Tiga Kontestan, Jakata: Pustaka Sinar Harapan.

Muluk, Saeful, 2000, "The Indonesian Army and Political Islam: A Political Encounter 19661977”, M.A Thesis belum ditebitkan, Montreal: Institute of Islamic Studies Mgrill University.

Hassan, Sahar, L., dkk., 1998, Memilih Partai Islam: Visi, Misi dan Persepsi, Jakarta: Gema Insani.

Putra, Lamkaruna. 2001, Perjalanan Panjang Aceh Menuju Islam Kaffah, Bekasi: Titian Ilmu Insani.

Romli, Lili, 2006, Islam Yes Partai Islam Yes: Sejarah Perkembangan Partai-Partai Islam di Indonesia, Jakarta: Pustaka Pelajar.

Siddiq, H. M. Dja'far, 2003, PPP Menggagas Reformasi Membangun Indonesia Baru, Jakarta: Tanpa Penerbit.

Sulaiman, M. Isa, 1997, Sejarah Aceh Sebuah Gugatan Terhadap Tradisi, Jakarta: Pustaka Sinar Harapan.

Sufi, Rusdi, 1997, Peranan Tokoh Agama dalam Perjuangan Kemerdekaan 1945-1950, Jakarta: Departemen Pendidikan dan Kebudayaan.

Thaba, Abdul Azis, 1966, Islam dan Negara dalam Politik Orde Baru, Jakarta: Gema Insani Press.

Thayeb, T. Hasyim, tt, Sejarah Singkat Fusi 4 Partai Islam, Tanpa Tempat: Tanpa Penerbit.

Tim Peneliti, 1985, Sejarah Tentang Pengaruh PELITA di Daerah Terhadap Kehidupan Masyarakat Pedesaan Propinsi Daerah Istimewa Aceh, Jakarta: Departemen Pendidikan dan Kebudayaan.

Truna, Dody S., tt, 'Islam and Politis Under The 'New Order' Government in Indonesia 19661990" M.A Thesis belum ditebitkan, Montreal: Institute of Islamic Studies Mgrill University.

Warjio, 2013, Dilema Politik Pembangunan PKS: Islam dan Konensional, Medan: Perdana Publishing. , 2018, Gagalnya Partai Politik Islam, Yogyakarta: Penerbit Pustaka Pelajar. 